\title{
Influences of Salinity, Light and Temperature on Seed Germination of Leucaena leucocephala (Lam.) de Wit.
}

\author{
Basalah, M. O. and H. M. Ali. ${ }^{1}$
}

\begin{abstract}
The experiment was investigated to study evaluate the seed germination of Leucaena leucocephala (Lam.) de Wit. under salinity, temperature, light and their interaction on the rate and final percentage of germination. The experiment was carried out in plant physiology laboratory at College of Science, King Saud University, Riyadh, Saudi Arabia. The collected seeds of Leucaena was treated with boiling water for 3 minutes then left to germinate in Petri dishes in growth chamber under the investigated treatments. Seven concentrations of sodium chloride solution had EC of $(0,50,100,300,400,500$ and $600 \mathrm{mM})$ were applied to seeds as irrigation water and exposed to three temperature degree $\left(20,30\right.$ and $\left.40{ }^{\circ} \mathrm{C}\right)$. Seeds untreated with $\mathrm{NaCl}$ germinated well in a wide range of temperatures and in both full light and complete dark. Seed germination decreased significantly with the increase in both $\mathrm{NaCl}$ concentration and temperature. Optimal germination percentage occurred at $30^{\circ} \mathrm{C}$. The inhibitory effect of high salinity on final germination percentage was greater at $40{ }^{\circ} \mathrm{C}$ than at 20 and $30{ }^{\circ} \mathrm{C}$. However, germination rate was significantly greater at $40{ }^{\circ} \mathrm{C}$ than at 20 and $30{ }^{\circ} \mathrm{C}$ in lower salinity and the reverse was true at higher salinity. Germination in light was significantly greater than in the dark at lower salinity levels and high temperature.
\end{abstract}

Keywords: Salinity, Seed germination, Temperature, Light, Leucaena leucocephala.

\section{INTRODUCTION}

Studies of environmental stresses for trees at different stages of development are very important for regeneration and consequently for successful establishment of plantations. Seed germination, as a critical stage in plant life is the most vulnerable to such stresses (Catalan et al., 1994). Salinity is one of the most important factors affecting seed germination in the arid regions. Studies showed that sodium chloride is the most important salt affecting seed germination. Its high concentrations inside the soil have an adverse effect on seed germination (Mayer and Mayber, 1982). The adverse effect is attributed to ionic toxicity and the decline in osmotic pressure which do interact under saline conditions (Greenway and Munns, 1980). The principal effects of salinity on seed germination could be summarized in the delay of seed germination, and the decline in its rate and percentage (Villagra, 1997). In
Saudi Arabia, saline water is one of the most frequent environmental stresses that face growing plants. This because groundwater represents more than $90 \%$ of water used in agricultural irrigation and it classified as very saline water (Falatah et al., 1999). They found that the salinity (EC) of groundwater from 400 samples represent eight agricultural regions of Saudi Arabia ranged between 0.2 and $29.3 \mathrm{dS} \mathrm{m}^{-1}$. Recently, AlMatroud (2003) reported that salinity of groundwater from Riyadh Region (Central part of Saudi Arabia) has electrical conductivities (EC) ranged between 1.34 and $7.84 \mathrm{dS} \mathrm{m}^{-1}$ and dominated by sodium chloride cations.

Leucaena leucocephala is a fast-growing, leguminous tree (Mimosaceae) that can be used for reforestation, for firewood, and as a forage crop. Leucaena is valued as an excellent protein source for cattle fodder, consumed browsed or harvested, mature or immature, green or dry. The nutritive value is equal to or superior to alfalfa. Leucaena has gained a favorable reputation in land reclamation, erosion control, water conservation, reforestation and soil improvement programs, and is a good cover and green manure crop. The leaves, used as mulch around other crops, are said to significantly increase their yields. It is said to possess the power of extracting selenium from the soil and concentrating selenium in the seed. This could be used to ameliorate seleniferous soils if the feed were discarded or used for some purpose other than feed. Seeds yield about 25 percent gum worthy of commercial investigation. Seeds after softening are strung as beans into various items of jewelry for tourists in Puerto Rico and the Virgin Islands. In the Philippine Islands, young pods are cooked as a vegetable and seeds are used as a substitute for coffee. Ripe seeds are sometimes eaten parched like popcorn (N.A.S. 1977). Wood is hard and heavy (specific gravity 0.7 ), the sapwood light yellow, the heartwood yellow-brown to dark brown, used for fuel or charcoal. Plants are used in some countries for shade for black pepper, coffee, cocoa, quinine, and vanilla and for hedges. In many places, however, renegade seedlings have created a noxious weed situation. The depilatory chemical mimosine has been used, experimentally at least, to shear sheep (Duke, 1981a, b). Medicinally, the bark is eaten for internal

\footnotetext{
${ }^{1}$ Department of Botany and Microbiology, College of Science, King Saud University. P.O. Box 2455, Riyadh 11451.

Saudi Arabia. (dr_basalah@yahoo.com).

Received February6, 2010, Accepted February24, 2010
} 
pain. A decoction of the root and bark is taken as a contraceptive, ecbolic, depilatory, or emmenagogue in Latin America. However, in experiments with cattle, leucaena had no effect on conception.

Leucaena leucocephala shows great potential for use as a multipurpose tree in different parts of the world, in comparison to several native and exotic species (Deans et al., 2003). In these regions, germination occurs during rainy seasons when soil salinity levels are usually reduced (El-Keblawy, 2004). Optimal germination in seeds of halophytes often occurs under fresh-water conditions and germination of most species is reduced and delayed with salinity increase, so the response may vary greatly depending on species. Whereas several perennial halophytes could germinate in $860 \mathrm{mM} \mathrm{NaCl}$ or more (Lyndlee and Kleindorfer, 2009). Other halophytes showed little germination above $125 \mathrm{mM}$ $\mathrm{NaCl}$ (Zygophyllum simplex, Khan and Ungar, 1996).

Temperature and salinity can interact in determining salinity tolerance during germination. Although higher salinity decreases germination, the detrimental effect of salinity is generally less severe at optimum temperature. The detrimental effect of salinity was found to be severe at higher temperatures in some species, including Atriplex cordobensis (Aiazzi et al., 2002), but at lower temperatures for other species.

Finally, salinity tolerance did not depend on temperature in some other species, such as Arthrocnemum indicum (Khan and Gul, 1998). Salinity, temperature interaction may have significant ecological implications in terms of time of germination under field conditions (Ungar, 1995); it has been attributed to both osmotic and toxic effects (Khan and Ungar, 1998).

Despite the number of extensive studies that report the interactive effects of salinity and temperature on germination, the influence of light in these responses is not clear (Gulzar et al., 2001).

The aim of this study was to evaluate the effect of salinity, temperature and light, and the interactions between these factors on final germination percentage of Leucaena leucocephala, grown under conditions of the arid environments of the Riyadh Region, Saudi Arabia.

\section{MATERIALS AND METHODS}

\section{Plant material}

Seeds of Leucaena leucocephala (Lam.) de Wit. Fam. (Mimosaceae) were collected from botanical garden of Department of Botany and Microbiology, College of Science, King Saud University. The collected seeds were cleaned then placed in boiling water for three minutes, as a well known pre-germination treatment for most leguminous seeds.

\section{Germination conditions and treatments}

Seeds used in germination experiments were not scarified. The germination was conducted in 9-cm Petridishes containing two disk of Whatman No. 1 filter paper, with $5 \mathrm{ml}$ of test solution. Dishes were wrapped with parafilm.

Germination experiments were conducted in growth chamber set at 20,30 and $40{ }^{\circ} \mathrm{C}$ in either continuous light or dark. Seeds were germinated in double distilled water (0), and in 50,100,300, 400, 500 and $600 \mathrm{mM}$ $\mathrm{NaCl}$ solutions under these temperature and light treatments. Four replicates of 25 seeds each were used for each treatment. The dishes were wrapped in aluminum foil to prevent any exposure to light (for dark treatment). Seeds were considered to be germinated with the emergence of the radicals. Germinated seedlings were counted and removed every alternate day, for 15 days following seed sowing.

The rate of germination was estimated using a modified Timson index of germination velocity $=\Sigma \mathrm{G} / \mathrm{t}$; where $G$ is the percentage of seed germination at $2 d$ intervals and $\mathrm{t}$ is the total germination period (Khan and Ungar, 1984).

\section{Statistical analysis}

RCBD was used for the experimental as described by Snedecor and Cochran (1968). A three-way analysis of variance (ANOVA) was carried out to test effects of main factors (salinity, light, temperature) and their interactions on the final percentage of germination. The effects of light on germination rate were not assessed as the germinated seedlings were counted only once, at the end of the experiment. Two-way ANOVA were performed to evaluate the effects of salinity and temperature on germination rate and the effects of light and temperature on germination percentages of non-salt treated seeds. All statistical methods were performed using SAS, (1990).

\section{RESULTS AND DISCUSSIONS}

\section{Effects on final germination}

The results indicate that non-salt treated seeds of Leucaena leucocephala germinated well in a wide range of temperatures and in both light and dark. Two-way ANOVA showed significant effects of temperature $(\mathrm{P}<0.001)$ and interactions between light and temperature $(\mathrm{P}<0.05)$ on final germination percentage of non-salt treated seeds (Fig. 1).

Results of three-way ANOVA showed significant effects for light, temperature and salinity on final germination \% of Leucaena leucocephala (Table 1). Seed germination decreased with the increase in both $\mathrm{NaCl}$ concentration and temperature. Few seeds 
germinated at $600 \mathrm{mM} \mathrm{NaCl}$. Optimal germination occurred at $30{ }^{\circ} \mathrm{C}$; seeds at both 20 and $30{ }^{\circ} \mathrm{C}$ germination attained significantly greater values than those at $40{ }^{\circ} \mathrm{C}$ (Fig. 1).

The interaction effect of temperature and $\mathrm{NaCl}$ concentration on final germination was significant $(\mathrm{P}<0.001$; Table 1), indicating that the germination response to salinity depended on temperature. The inhibitory effect of high salinity on final germination was greater at $40{ }^{\circ} \mathrm{C}$ than at 20 and $30{ }^{\circ} \mathrm{C}$. Despite the fact there were no great differences in final germination between 0 and $400 \mathrm{mM} \mathrm{NaCl}$, at either $20^{\circ} \mathrm{C}$ or at $30^{\circ} \mathrm{C}$,

Table 1. three-way ANOVA showing influences of salinity, light and temperature on Leucaena leucocephala

\begin{tabular}{lcccc}
\hline \multicolumn{1}{c}{ Source of variation } & df & Mean-square & F-ratio & P \\
\hline Temperature $(\mathrm{T})$ & 2 & 4.937 & 520.534 & $<0.001$ \\
\hline $\mathrm{NaCl}$ conc. $(\mathrm{S})$ & 6 & 2.077 & 230.531 & $<0.001$ \\
\hline $\mathrm{Light}(\mathrm{L})$ & 1 & 0.050 & 5.936 & $<0.05$ \\
\hline $\mathrm{T} * \mathrm{~S}$ & 12 & 0.247 & 29.157 & $<0.001$ \\
\hline $\mathrm{T} * \mathrm{~L}$ & 2 & 0.049 & 6.117 & $<0.01$ \\
\hline $\mathrm{S} * \mathrm{~L}$ & 6 & 0.019 & 2.025 & 0.210 \\
\hline $\mathrm{T} * \mathrm{~S} * \mathrm{~L}$ & 12 & 0.014 & 1.904 & $<0.05$ \\
\hline Error & 126 & 0.0086 & \multicolumn{3}{c}{ Germination in $30^{\circ} \mathrm{C}$}
\end{tabular}
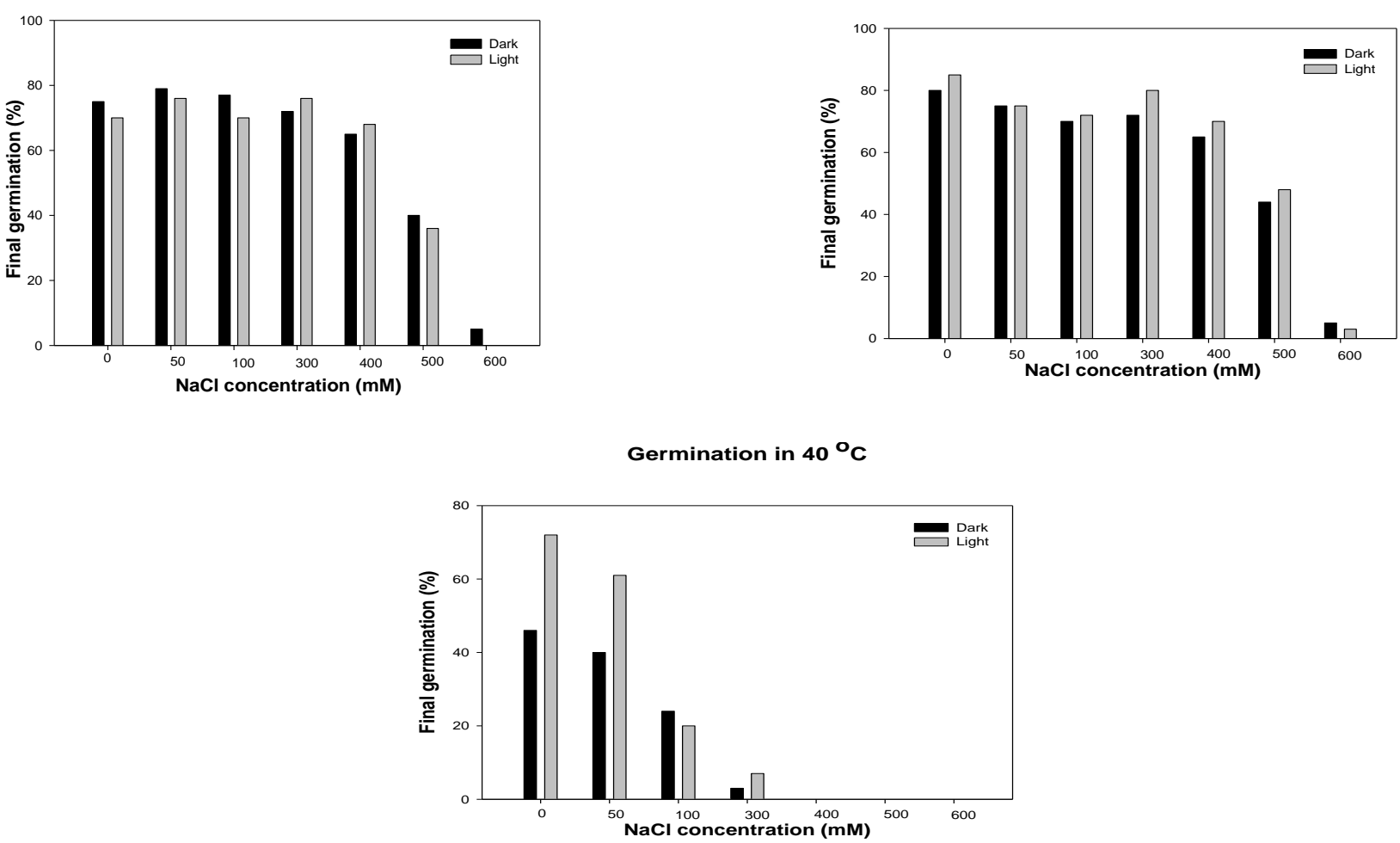

Fig. 1. Influences of salinity, light and temperature on final germination percentage in Leucaena leucocephala germination at $40{ }^{\circ} \mathrm{C}$ was greatly reduced in $300 \mathrm{mM}$ conditions. The interaction between light and temperature on final germination was significant $(\mathrm{P}<0.01$; Table 1). Whereas no significant difference in final germination was observed between light and dark at either 20 or $30{ }^{\circ} \mathrm{C}$, the germination in light was significantly greater than in the dark at $40{ }^{\circ} \mathrm{C}$ (Fig. 1).

\section{Germination in $40^{\circ} \mathrm{C}$}


The interaction among salinity, temperature and light on final germination was also significant $(\mathrm{P}<0.05$; Table1). Germination in light did not differ significantly from that in dark in any of the concentrations of $\mathrm{NaCl}$ at either 20 or $30{ }^{\circ} \mathrm{C}$. At $40{ }^{\circ} \mathrm{C}$ however, germination in light was significantly greater than in dark, for seeds treated with lower salinities (0 and $50 \mathrm{mM} \mathrm{NaCl}$ ). Moreover, at this temperature, few seeds germinated in the $300 \mathrm{mM}$ and none in $500 \mathrm{mM} \mathrm{NaCl}$. Germination at 0 and $400 \mathrm{mM} \mathrm{NaCl}$ increased from $49.2 \%$ and $41.3 \%$ for seeds incubated in dark to $72.4 \%$ and $66.2 \%$ for seeds incubated in light, respectively (Fig. 1).

Seed dormancy in plants growing in saline habitats of subtropical deserts is often regulated by salinity and temperature. Dormancy reduces the risk of seedling mortality, when moisture is limited and salinity is increased (during summer). For example, in the desert annual Zygophyllum simplex, germination occurs only when temperature and salinity were reduced, but this happen either during winter or after monsoon rain (Khan and Ungar, 1997). Germination was also greatly reduced in several perennial halophytes at higher temperatures and salinities (Aiazzi et al., 2002; Khan et al., 2002).

In the present study, the inhibitory effect of high salinity was greater at $40{ }^{\circ} \mathrm{C}$ than at 20 and $30{ }^{\circ} \mathrm{C}$. Few seeds germinated in $400 \mathrm{mM} \mathrm{NaCl}$ and no germination occurred in $500 \mathrm{mM} \mathrm{NaCl}$ at $40{ }^{\circ} \mathrm{C}$ (Fig. 1).

The detrimental effect of $\mathrm{NaCl}$ at higher temperatures has been attributed to toxicity of $\mathrm{Na}^{+}$that usually causes irreversible damage (Al-Khateeb, 2006). In Atriplex cordobensis, however, water stress resulted from either high salinity or polyethylene glycol (Aiazzi et al., 2002) caused germination inhibition at higher temperatures, what suggests that the mechanism of $\mathrm{Na}^{+}$ toxicity may not be present in some species. The inhibitory effect of salinity at higher temperatures has ecological significance because it prevents seeds from germinating in salt-affected habitats and consequently avoiding seedling mortality during this period when surface soil salinities are extremely high (Khan and Ungar, 1998). This could be true if the damage caused by $\mathrm{Na}^{+}$toxicity is not irreversible.

\section{Effects on germination rate}

Results of two-way ANOVA showed significant effects for temperature and salinity on germination rate of Leucaena leucocephala ( $\mathrm{P}<0.001$; Table 2$)$.

Germination rate decreased significantly with the increase in salinity. Overall germination rate at 0 and $50 \mathrm{mM} \mathrm{NaCl}$ (35.6 and $37.1 \%$, respectively) was significantly greater than in higher concentrations (Fig. 2 ). The interaction between temperature and $\mathrm{NaCl}$ concentration on germination rate was significant $(\mathrm{P}<0.001$; Table 2). Unlike germination percentage, germination rate at $40{ }^{\circ} \mathrm{C}$ attained significantly greater values than at $20^{\circ} \mathrm{C}$, for seeds treated with 0 and $50 \mathrm{mM}$ $\mathrm{NaCl}$. The increase in $\mathrm{NaCl}$ to 100 and $200 \mathrm{mM}$ resulted in a significant decrease in germination rate at $40{ }^{\circ} \mathrm{C}$ compared to 20 and $30{ }^{\circ} \mathrm{C}$. Germination rate at $30{ }^{\circ} \mathrm{C}$ was less affected by salinity increase than at $20^{\circ} \mathrm{C}$. For seeds treated with 500 and $600 \mathrm{mM} \mathrm{NaCl}$, the germination rate at $30{ }^{\circ} \mathrm{C}$ was significantly greater than at $20{ }^{\circ} \mathrm{C}$ (Fig. 2).

The present study showed that about $57 \%$ of the non-salt treated seeds of Leucaena leucocephala germinated at $40{ }^{\circ} \mathrm{C}$, suggesting that the temperature in non-saline habitats is not a limiting factor, if moisture is available during summer months. Many seedlings have been observed after summer rainfalls that typically occur in the tropical and subtropical environments, where Leucaena leucocephala grows naturally. In arid deserts, surface layers of soils often dry out quickly due to evaporation or rapid penetration, and water is stored below the soil surface, where a considerable amount may remain available to plants (Ghorbanli et al., 2001). Faster germination recorded in Leucaena leucocephala at $40{ }^{\circ} \mathrm{C}$ (Fig. 2) might enhance seedling emergence shortly after summer germination episodes. Consequently, seedling roots will grow when the surface layer of soil is still wet. This could secure seedling survival through the rapid growth of roots enabling them to reach a moist layer of soil.

Ismail (1998) reported that Leucaena leucocephala is equipped with a number of biological characteristics that can facilitate its rapid invasion of new areas. The present study demonstrated that a significant proportion of non-salt treated seeds of Leucaena leucocephala germinated under a wide range of temperatures and in both light and dark. This could be another reason behind the successful invasion of this species in several tropical and subtropical countries of the world.

In many plant species, light is one of the most important environmental regulatory signals that interact with temperature to regulate seed germination (Baskin and Baskin, 1998). Light requirement for germination may vary with temperature. Nosignificant difference between light and dark germination at 20 and $30{ }^{\circ} \mathrm{C}$, for both non-saline and saline treated seeds, were found for Leucaena leucocephala. However, at the highest temperature $\left(40{ }^{\circ} \mathrm{C}\right)$, germination in light was significantly greater than in darkness (Fig. 1). Similar results were reported for the cosmopolitan annual plant species, Portulaca oleracea, (El-Keblawy and AlAnsari, 2000). 
Table 2. Two-way ANOVA showing influences of salinity and temperature on Leucaena leucocephala

\begin{tabular}{lcccc}
\hline Source of variation & df & Mean-square & F-ratio & P \\
\hline Temperature $(\mathrm{T})$ & 2 & 759.148 & 39.731 & $<0.001$ \\
\hline $\mathrm{NaCl}$ conc. $(\mathrm{S})$ & 6 & 2376.861 & 118.736 & $<0.001$ \\
\hline $\mathrm{T} * \mathrm{~S}$ & 12 & 193.190 & 9.938 & $<0.001$ \\
\hline Error & 63 & 19.340 & & \\
\hline
\end{tabular}

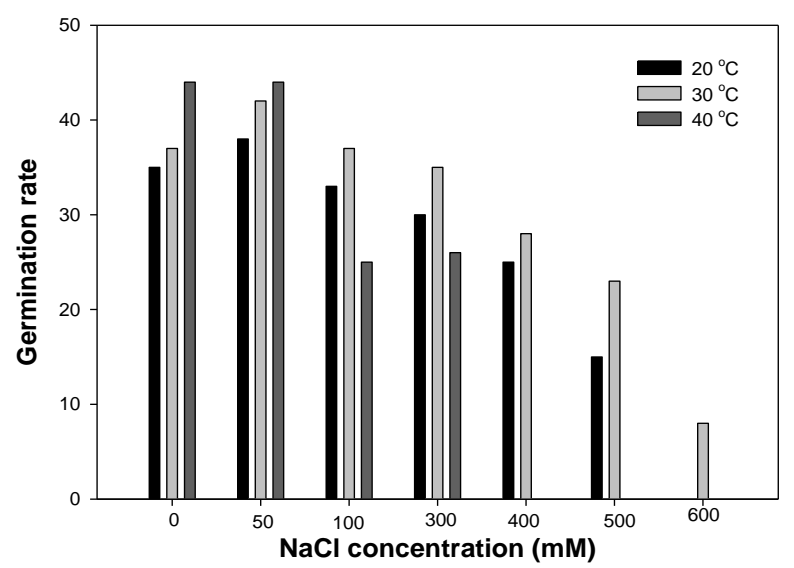

\section{Fig. 2. Influences of salinity and temperature on germination rate in Leucaena leucocephala}

Light is abundant only on the soil surface and physiologically active light flux rarely penetrates more than a few millimetres into soil. Shiferaw et al. (2004) indicated that Prosopis juliflora is characterized by the accumulation of a long-lived seed bank that serves as a source of regeneration of new plants in the event of disturbance. The mean soil seed density, from the top of the litter layer down to $9 \mathrm{~cm}$ depth, was estimated to be 1932 seeds $/ \mathrm{m}^{2}$. Greater germination of $P$. juliflora seeds at $40{ }^{\circ} \mathrm{C}$ in light than in dark suggests germination in summer may benefit by more light and seeds in upper layer of litter would have a greater chance for emergence than seeds buried in deeper layers. This would maintain the seed bank of this species, especially as leading to seedling recruitment following summer rainfall very low.

Light and salinity interact during germination in a number of other halophytes. For example, the increase in $\mathrm{NaCl}$ concentration progressively inhibited seed germination in Allenrolfea occidentalis, and this inhibition was greater in the dark than in light (Gul and Weber, 1999). Also, both darkness and high salinity inhibited germination of Limonium stocksii (Jie et al., 2008). The interaction effect of salinity and light on germination of Leucaena leucocephala was not significant (Table 1), indicating that the effect of salinity may not necessarily depend on light conditions in this species.

The present study showed that the optimal germination for non-salt treated seeds (90\%) of Leucaena occurred at $30^{\circ} \mathrm{C}$ and in continuous light (Fig. 1), a high germination percentage for seeds did not receive any pre-treatment. High germination for untreated seeds of Leucaena leucocephala at optimal conditions could be attributed to seed storage that broke any seed dormancy. Several studies have shown that Leucaena leucocephala has a physical dormancy (Scifres and Brock, 1969). This dormancy can be broken by seed pre-treatment with sulphuric acid (Agus, 2007), by passing through the digestive track of animals, and by the treatment with boiling water.

\section{REFERENCES}

Aiazzi, M.T.; P.D. Carpane; J.A. Rienzo and J.A. Arguello, (2002). Effects of salinity and temperature on the germination and early seedling growth of Atriplex cordobensis Gandoger et Stuckert (Chenopodiaceae). Seed Sc. Tech. 30, 329-338.

Al-Khateeb, S. A., (2006). Effect of salinity and temperature on germination, growth and ion relations of Panicum turgidum Forssk. Bioresource Technology 97: 292-298. 
Al-Matroud S. S., (2003). Evaluation of irrigation water quality and its effect on soil infeltration rate in riyadh region. MSc. Thesis. College of Agriculture, King Saud University, Saudi Arabia.

Baskin, C.C. and Baskin, J.M., (1998). Seeds: ecology, biogeography, and evolution of dormancy and germination. Academic Press, San Diego.

Catalan, L.; M. Balzarini; E. Taleisnik; R. Sereno and U. Karlin. (1994). Effects of salinity on germination and seedling growth of Prosopis flexuosa (D.C.). Forest Ecol.Manag. 63: 347-357.

Deans, J.D.; O.Diagne; J. Nizinski; D.K. Lindley; M. Seck; K. Ingleby and R.C. Munro, (2003). Comparative growth, biomass production, nutrient use and soil amelioration by nitrogen-fixing tree species in semi-arid Senegal. Forest Ecol.Manag.176, 253-264.

Duke, J.A., (1981a). Handbook of legumes of world economic importance. Plenum Press. NewYork.

Duke, J.A., (1981b). The gene revolution. Paper 1. p. 89-150. In: Office of Technology Assessment, Background papers for innovative biological technologies for lesser developed countries. USGPO. Washington.

El-Keblawy, A. and F. Al-Ansari, (2000). Effect of site of origin, time of seed maturation and seed age on germination behavior in Portulaca oleracea L. from Old and New World. Canad. J. Bot. 78, 279-287.

El-Keblawy, A., (2004). Salinity effects on seed germination of the common desert range grass, Panicum turgidum. Seed Sci. Tech. 32, 943-948.

Falatah, A. M.; A. Al-Omran; M. E. Nadeem and M. M. Mursi, (1999). Chemical composition of irrigation groundwater used in irrigation in some agricultural regions of Saudi Arabia. Emirates J. Agr. Sci. 1: 11-23.

Ghorbanli, M.; H. Hekmatshear and F. Farahvash., (2001). The correlation of temperature and salinity variations on seed germination of two Atriplex species of Azarbijan. J. Agri. Sci. (Islamic Azad University) 6(4): 33-46.

Greenway, H. and R. Munns. (1980). Mechanisms of salt tolerance in nonhalophytes. Ann. Rev.Plant Physio. 31: 159-190.

Gul, B. and D.J. Weber, (1999). Effect of salinity, light, and temperature on germination in Allenrolfea occidentalis. Cana. J. Bot. 77, 240-246.

Gulzar, S.; M.A. Khan and I.A. Ungar, (2001). Effect of salinity and temperature on the germination of Urochondra setulosa (Trin.) C.E. Hubbard. Seed Sci.Techno. 29, 21-29.

Ismail, S., (1998). Physiology of salt tolerance in some fodder plants. Ph.D. Thesis Univ. Karachi, Pakistan.
Jie, S.; H. F., Yuanyuan; Y. Jia; X. Du and B. Wang, (2008). Effect of salinity on germination, seedling emergence, seedling growth and ion accumulation of a euhalophyte Suaeda salsa in an intertidal zone and on saline inland. Aquatic Botany 88: 331-337.

Khan, M.A. and B. Gul, (1998). High salt tolerance in germinating dimorphic seeds of Arthrocnemum indicum.Inter. J. Plant Sci. 159, 826-832.

Khan, M.A. and I.A. Ungar, (1984). The effect of salinity and temperature on the germination of polymorphic seeds and growth of Atriplex triangularis Willd. Amer. J. Bot. 71, 481-489.

Khan, M.A. and I.A. Ungar, (1996). Alleviation of seed dormancy in the desert forb Zygophyllum simplex L. from Pakistan. Ann. Bot. 80, 395-400.

Khan, M.A. and I.A. Ungar, (1997). Germination responses of the subtropical annual halophyte Zygophyllum simplex. Seed Sci. Techno. 25, 83-91.

Khan, M.A. and I.A. Ungar, (1998). Seed germination and dormancy of Polygonum aviculare L. as influenced by salinity, temperature, and gibberellic acid. Seed Sci.Techno. 26, 107-117.

Khan, M.A.; B. Gul and D.J. Weber, (2002). Seed germination in relation to salinity and temperature in Sarcobatus vermiculatus. Biologia Plantarum 45, 133-135.

Lyndlee, C. E. and S. Kleindorfer, (2009). Effects of salinity levels and seed mass on germination in Australian species of Frankenia L. (Frankeniaceae). Enviro. Experim. Bot. 65: 345-352.

Mayer, A. M. and P. Mayber. (|1982). The germination of seeds. Pergamon Press,Oxford.

N.A.S. (1977). Leucaena: promising forage and tree crop for the tropics. National Academy of Sciences, Washington, DC.

SAS, (1990). SAS user's guide. SAS Institute. Cary, North Carolina, USA.

Scifres, C.J. and J.H. Brock, (1969). Mosisture-temperature interrelations in germination and early seedling development of mesquite. J. Range Manag. 22, 453-458.

Shiferaw, H.; D.,Teketay; S. Nemomissa and F. Assefa, (2004). Some biological characteristics that foster the invasion of Prosopis juliflora (Sw.) D.C. at Middle Awash Rift Valley Area, north-eastern Ethiopia. J. Arid Env. 58, 134-153.

Snedecor, G.W. and W.G. Cochran, (1968). Statistical methods. Sixth edition. The Iowa State Univ. Press Ames. Iowa, USA.

Ungar, I.A., (1995). Seed germination and seed-bank ecology of halophytes. In: Kigel, J., Galili, G. (Eds.), Seed Development and Germination. Marcel Dekker Inc., New York, pp. 599-629.

Villagra, P. E. (1997). Germination of Prosopis argentina and Prosopis alpataco seeds under saline conditions. J. Arid Envir. 37: 261-267. 


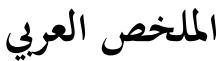

\section{تأثيرات الملوحة والضوء ودرجات الحرارة علي إنبات بذور أشجار اللوسينيا}

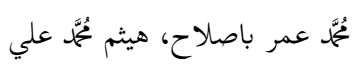

بالمعاملة بالضوء أو الظلام التام. وقد الخفضت نسبة النية انبات بذور اللوسينيا معنويا وذلك بزيادة كلا من تركيز املاح كلوريد الصوديوم و

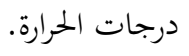

وقد كانت نسبة الأنبات الامثل في درجة حرارة 30 م م وكان

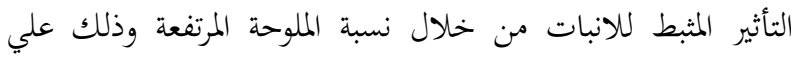

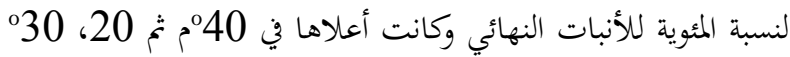

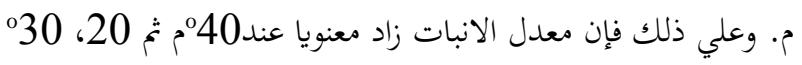
م بالمعاملة بتركيزات الملوحة المنخفضة والعكس صحيح في معدلات

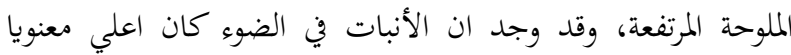

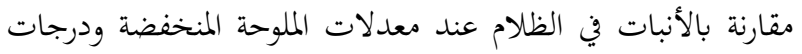

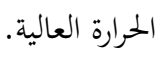

أجريت هذه الدراسة لتقييم إنبات بذور أشجار اللوسينيا وذلك

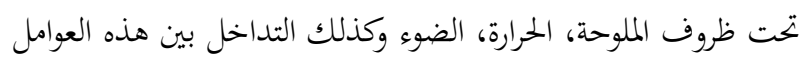
وثأثيرها علي معدل نسبة الأنبات النهائية لبذور اشجار اللوسينيا. أجريت هذه التجربة داخل معمل فسيولوجيا النبات بكلية العلوم

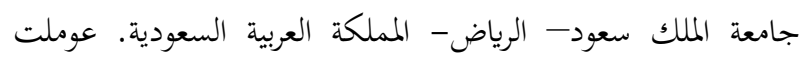
البذور بلماء المغلي لمدة ثلاث دقائق وذلك قبل وضعها في اطباق بتري داخل غرف النمو في ظروف بيئية متحكم هما. وقد أستخدم سبع تركيزات مختلفة من أملاح كلوريد الصوديوم

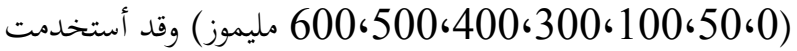

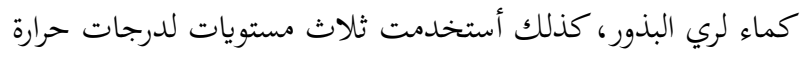

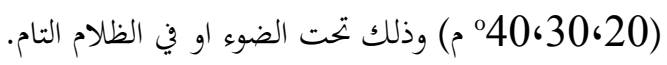

وقد أعطت البذور الغير معاملة بكلوريد الصوديوم نسبة عالية من الأنبات علي نطاق واسع من درجات الحرارة المختلفة وذلك سواء 